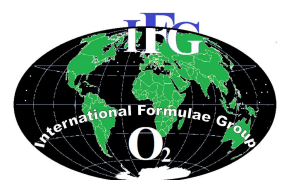

Available online at http://ajol.info/index.php/ijbcs

Int. J. Biol. Chem. Sci. 9(1): 552-562, February 2015

International Journal

of Biological and

Chemical Sciences

ISSN 1997-342X (Online), ISSN 1991-8631 (Print)

Original Paper

http://indexmedicus.afro.who.int

\title{
The quality of drinking water used by the communities in some regions of Uganda
}

\author{
James OKOT-OKUMU ${ }^{1 *}$ and Jacob OTIM ${ }^{2}$ \\ ${ }^{I}$ Department of Environmental Management, College of Agricultural \& Environmental Sciences, \\ Makerere University P.O.Box 7062. Kampala, Uganda. \\ ${ }^{2}$ Ministry of Water and Environment, Directorate of Water Resources Management, \\ Entebbe, P.O.Box 20026 Kampala, Uganda. \\ *Corresponding author; E-mail: jokotokumu@caes.mak.ac.ug; jokotokumu@yahoo.com; \\ jokotokumu59@gmail.com
}

\begin{abstract}
The study was done to assess the suitability of drinking water sources used by some communities in Uganda and the associated consumption risks. Water samples were collected, treated and tested according to standard methods of the American Public Health Association (APHA). Results of physicochemical and microbiological parameters were: $\mathrm{NO}_{3}^{-}(0.01-4.6 \mathrm{mg} / \mathrm{l})$; turbidity $(<5-97.6 \mathrm{NTU})$; Total dissolved solids (59$420.9 \mathrm{mg} / \mathrm{l})$; conductivity $(28-760 \mu \mathrm{S} / \mathrm{cm}) ; \mathrm{pH}(5.3-7.2)$; temperature $\left(23-25.90{ }^{\circ} \mathrm{C}\right)$, total coliform $(0-940$ $\mathrm{cfu} / 100 \mathrm{ml})$, faecal coliform $(0-200 \mathrm{cfu} / 100 \mathrm{ml})$. Risk of Contamination (ROC) assessment agreed with water quality analysis that found boreholes to be the safest $(<1 \mathrm{CFU} / 100 \mathrm{~mL})$ water source, followed in order by rainwater, standpipe taps and protected springs. Shallow wells, unprotected springs and surface water (e.g. streams) were high risk ( $\geq 100 \mathrm{CFU} / 100 \mathrm{~mL}$ ) water sources. Nitrate-nitrogen, faecal coliform and total coliform were higher than WHO standards for drinking water in most of the water springs and wells. The management of community water sources is discussed.
\end{abstract}

(C) 2015 International Formulae Group. All rights reserved.

Keywords: Bacteriological, risk of contamination, physicochemical, communities water sources.

\section{INTRODUCTION}

It is common in most African countries for the poor communities to use non-piped water that are predominantly from shallow groundwater sources. The water is used for drinking sanitation and other domestic chores. The alternative water sources (often shallow wells) to piped water are often polluted (Howard et al., 2003; Nsubuga et al., 2004;
Haruna et al., 2005; Cronin et al., 2006; Awomeso et al., 2010). The communities relying on such water sources often live in congested and polluted environment in periurban slums or in rural areas. In these circumstances, direct pollution of water sources by the users, by livestock and by wastewater, may be a serious problem of high health risks to users (WHO/UNICEF, 2000). 
Previous studies have concluded that contamination from on-site sanitation is a principal cause of water source pollution (Cronin et al., 2006; Horak et al., 2010). Suggested causes of pollution of community water are poor maintenance of sanitation facilities, unprotected wells and poor sanitary conditions (Aboyeji, 2013; Galadima et al., 2011). In most low-income communities there is lack of sanitation facilities so faeces are disposed of in the most unsafe ways. Worldwide, water-borne diseases are a major cause of morbidity and mortality in humans (WHO/UNICEF, 2014). It is therefore important to identify the sources of faecal contamination of water sources in order for interventions to protect community water sources to be effective.

The use of groundwater sources is common among Ugandan urban poor and rural communities. Although these water sources are to alleviate water supply problems to the poor communities, they are more exposed to contamination risks compared to the centrally controlled piped water distribution system. The alternative water sources are prone to pollution due to poor sanitation and indiscriminate waste dumping due to low sanitation coverage. For example, connection to central sewerage network is very low in most urban centres of Uganda (e.g. below 5\% in Kampala), majority of the population therefore practice onsite sanitation with increased risk of environmental pollution. This is evident by the outbreak water related diseases among these communities especially at the onset of rainy seasons (Howard et al., 2003; Nsubuga et al., 2004; Haruna et al., 2005). Furthermore, the use of non-piped water has been correlated to the outbreak of acute diarrhoea (Tumwine et al., 2002; Wolf et al., 2014).

In Ugandan peri-urban areas boreholes, springs and piped water are the sources of water for domestic use but provision of treated piped water is concentrated in high-income zones with little provision in the high-density, poor communities zones where the majority of the urban population reside. In rural areas, there is no piped water except in Rural Growth Centres (RGC) and the population depend mostly on unprotected shallow wells. Though spring water is considered to be aesthetically acceptable for domestic use, they may be contaminated by poor sanitation facilities like pit latrines, catchment erosion, wastewater and solid wastes that are improperly managed in these zones. Previous studies of community water supply in Kampala have all indicated serious pollution problems (Haruna et al., 2005; Howard et al., 2003; Nsubuga et al., 2004). This study was undertaken in selected rural and urban areas of Uganda to examine the quality of water consumed by poor communities and the associated risks of pollution of the water sources.

\section{MATERIALS AND METHODS}

The study was conducted in three urban centres: Kampala City, Gulu Municipality and Lira Municipality; and two rural areas of Iganga, Gulu and Nwoya District. The water sources for the study were from peri-urban and rural areas. The water sources were grouped per category and based on the location, selected randomly in close consultation with the Local Administration Institution- the Local Councils (LCs). Water samples were collected from administrative parishes since it is known that community collection of water from outside their parishes is uncommon (Howard et al., 2002). Water source selection criteria were: 1) existence of at least three types of water sources (e.g. borehole, standpipe and protected spring) in the area; 2) water source being public and 3) economic status of the community using the water source. In the rural areas, in most cases, all the water sources for the selected parishes were sampled because they were few.

In situ measurements included the determination of temperature $\left({ }^{\circ} \mathrm{C}\right), \mathrm{pH}$, electrical conductivity ( $\mu \mathrm{Scm}-1)$ and total dissolved solids (TDS/mgl-1) using hand held meters (Electrode probe WTW TA 197pH/T; 
Hach 4460000 conductivity meter) after calibration on each day of measurement. Water samples were taken from the different water sources, treated and analysed according to American Public Health Association (APHA) Standard Methods for the Examination of Water and Wastewater (APHA 2000). Water quality parameters analysed in the laboratory were nitrate, turbidity, faecal coliform and total coliform.

Sanitary risk inspection of the water sources were done during water sampling. Risk of contamination scoring (ROC) was done according to WHO (1997) on a scale of 0 to 10 score $(0-100 \%)$. Water sources were classified as low risk (0-2); intermediate risk (3-5); high risk (6-8) and very high risk (9-10) based on positive answers to ten risk assessment questions that varied depending on the water source assessed. The ROC examination together with the actual measurement of bacterial contamination (total coliform/100 $\mathrm{ml}$ (TC) and Faecal coliform/100 ml (FC)) were done to evaluate the level of potential exposure risk to the communities that use the water sources for drinking.

An alternative rapid characterisation was done by designating water with $<10$ CFU/100 $\mathrm{ml}$ as good (low risk), 10-100 $\mathrm{CFU} / 100 \mathrm{ml}$ as questionable (intermediate risk) and $>100 \mathrm{CFU} / 100 \mathrm{ml}$ as poor (high risk) by source type (e.g. boreholes, springs, well). Statistical analysis (t-test, and ANOVA) was done to compare the water sources using Microsoft Excel 2007. Correlation analysis was used to test the link between ROC score faecal contamination indicators and physicochemical parameters. In all cases significance was set at $\mathrm{p}=0.05$.

\section{RESULTS}

The determined water quality parameters were: $\mathrm{NO}_{3}^{-} \quad(0.01-4.6 \mathrm{mg} / \mathrm{L})$; turbidity (<5-97.6 NTU); TDS (59- 420.9 $\mathrm{mg} / \mathrm{L})$; conductivity $(28-760 \mu \mathrm{S} / \mathrm{cm}) ; \mathrm{pH}(5.3-$ 7.2); temperature $\left(23-25.90{ }^{\circ} \mathrm{C}\right)$; total coliform
(0- $940 \mathrm{cfu} / 100 \mathrm{ml}$ ); faecal coliform (0 - 200 cfu ml). Table 1 presents physicochemical and microbiological water quality data and Table 2 illustrates risk assessments scores for the water sources. Forty two percent $(42 \%)$ of the water sources did not meet the bacteriological guidelines for drinking water standards (WHO, 2011; UNBS, 2008).

The results of this study emphasize vulnerability of water sources used by poor communities in Uganda based on the level of faecal contamination (Tables 1, 2, 3). This is illustrated further by the WHO rural water sources classification applied in this study (Figure 1), that indicated boreholes to be the safest water source followed by rainwater and taps. Protected springs pose moderate risks, while shallow wells, unprotected springs and surface water are high risk water sources. Assessment of transformed bacteriological data for contamination lower than 1 CFU/100ml were: $21 \%$ standpipe taps, $17 \%$ Springs, 34\% harvested rainwater, 52\% boreholes and $0 \%$ shallow Wells as safe water sources for community consumption (Figure 1). It is only some of the protected springs among the water springs that scored lower than1 CFU/100 ml. All unprotected springs and wells scored higher than $1 \mathrm{CFU} / 100 \mathrm{ml}$, indicating public health risk.

Results of risk of contamination (ROC) assessment scores were from zero to ten (0$100 \%)$. The classification placed the water sources in four categories: Low (mostly taps, boreholes and rainwater); Intermediate (mostly protected springs); high (Unprotected springs); very high (shallow wells and surface water sources). Within the classification groups types, the water sources were not significantly different $(\mathrm{p}<0.05)$. Across the classes boreholes, taps and rainwater were not significantly different (ANOVA, p<0.05). ROC correlated strongly with faecal contamination (faecal coliform $\left.\mathrm{y}=0.1096 \mathrm{x}+0.077 ; \mathrm{R}^{2}=0.8672\right)$ and weakly with the nutrient $\mathrm{NO}_{3}^{-}(\mathrm{y}=0.1751 \mathrm{x}+0.0282$; $\left.\mathrm{R}^{2}=0.159\right)$ as illustrated by Figure 2. 


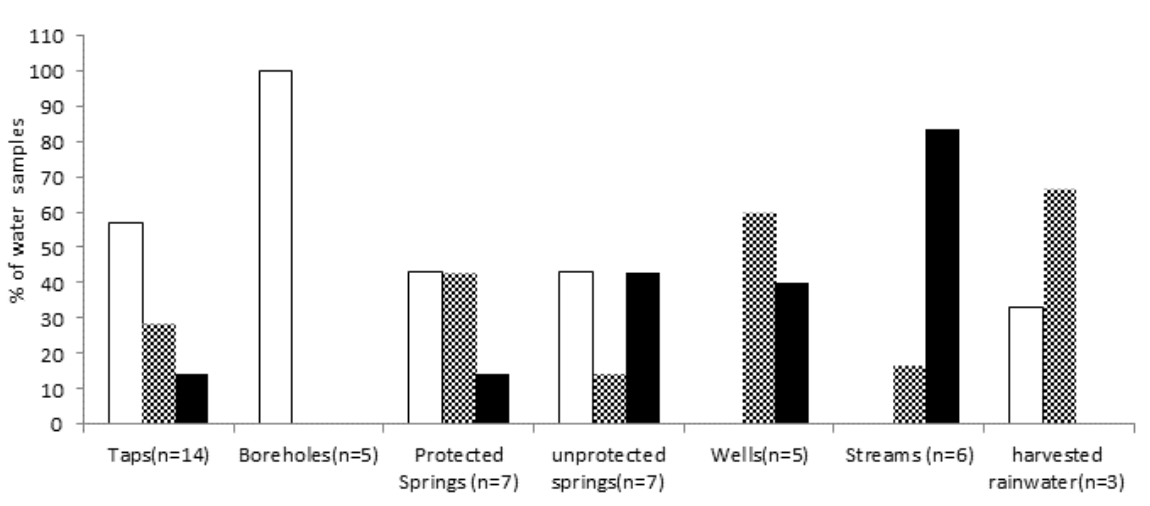

Figure 1: Water source classification based on Total Coliform count.
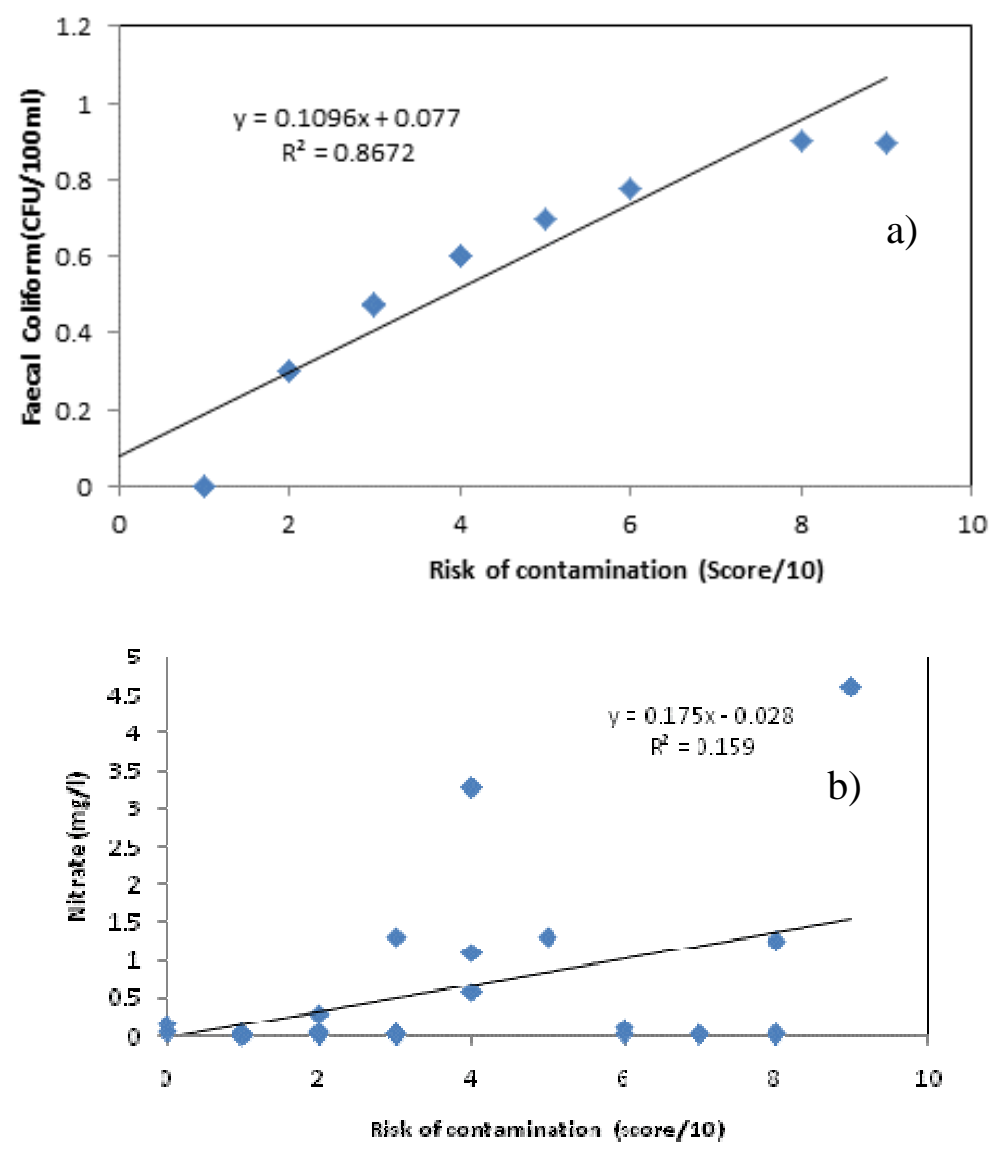

Figure 2: Regression analysis of risk of contamination scores with (a) faecal coliform and (b) $\mathrm{NO}_{3}^{-}$. 


\section{J. OKOT-OKUMU and J. OTIM / Int. J. Biol. Chem. Sci. 9(1): 552-562, 2015}

Table 1: Physiochemical and bacteriological quality of communities water sources.

\begin{tabular}{|c|c|c|c|c|c|c|c|c|}
\hline Water sources & $\begin{array}{c}\text { Temp } \\
{ }^{\circ} \mathrm{C} \\
\end{array}$ & pH & $\begin{array}{c}\mathrm{EC} \\
\mu \mathrm{S} / \mathrm{cm} \\
\end{array}$ & $\begin{array}{r}\text { TDS } \\
\mathrm{mg} / \mathrm{L} \\
\end{array}$ & $\begin{array}{c}\text { Turbidity } \\
\text { NTU }\end{array}$ & $\mathrm{NO}_{3}^{-} \mathrm{mg} / \mathrm{l}$ & $\begin{array}{c}\text { Total Coliform } \\
\text { cfu/100ml }\end{array}$ & $\begin{array}{c}\text { Faecal Coliform } \\
\text { cfu/100 ml }\end{array}$ \\
\hline \multicolumn{9}{|c|}{ Standpipes } \\
\hline T1:KLA(Makindye-Wabigalo) & 24.4 & 6.9 & 139 & 81.4 & $<5$ & 0.02 & $0-68$ & $0-2$ \\
\hline T2: :KLA(Makindye-Wabigalo) & 24.0 & 6.8 & 143 & 83.4 & $<5$ & 0.02 & $0-80$ & $0-3$ \\
\hline T3: :KLA(Makindye-Wabigalo) & 24.7 & 6.7 & 199 & 113.7 & $<5$ & 0.11 & $0-102$ & $0-6$ \\
\hline TL1:Lira (Ojwina-Kakooge A) & 23.6 & 7.1 & 37 & ND & ND & 0.02 & $0-0.4$ & 0 \\
\hline TL2: Lira (Ojwina-Kakooge A) & 25.2 & 6.9 & 31 & ND & ND & 0.01 & $0-0.4$ & 0 \\
\hline TL3: Lira (Ojwina-Aduku Road) & 23.6 & 7.1 & 28 & ND & ND & 0.02 & 0 & 0 \\
\hline NT1: KLA (Nattete ) & 24.3 & 6.4 & 100 & 61 & $<5$ & 0.06 & $1-3$ & $0-1$ \\
\hline NT2: KLA(Nattete) & 24 & 6.7 & 109 & 64 & $<5$ & 0.05 & $1-5$ & $1-2$ \\
\hline NT3: KLA(Nattete) & 24.2 & 6.7 & 98 & 63 & $<5$ & 0.17 & $1-3$ & $0-1$ \\
\hline WT1:KLA (Wabigalo) & 24.4 & 6.9 & 139 & 81.4 & $<5$ & 0.02 & $0-68$ & $0-2$ \\
\hline WT2:KLA (Wabigalo) & 24.0 & 6.8 & 143 & 83.4 & $<5$ & 0.02 & $0-8$ & $0-3$ \\
\hline WT3: KLA Wabigalo) & 24.7 & 6.7 & 199 & 113.7 & $<5$ & 0.11 & $0-102$ & $0-6$ \\
\hline \multicolumn{9}{|c|}{ Spring } \\
\hline NS1(P):KLA (Nattete) & 24.2 & 6.3 & 149 & 76 & $<5$ & 1.3 & $180-320$ & $174-200$ \\
\hline NS2(NP):KLA(Nattete) & 24.5 & 5.7 & 289 & 182 & $<5$ & 1.1 & $159-320$ & $140-217$ \\
\hline NS3(NP):KLA(Nattete) & 24.4 & 6.4 & 208 & 212 & $<5$ & 0.6 & $40-940$ & $80-138$ \\
\hline NS4(NP KLA(Nattete) & 24.3 & 6.3 & 398 & 59 & $<5$ & 3.3 & $42-289$ & $114-180$ \\
\hline NS5(P):KLA (Nattete) & 24.2 & 5.8 & 146 & 67 & $<5$ & 0.3 & $7-25$ & $5-15$ \\
\hline NS6(P): KLA (Nattete) & 24.4 & 5.8 & 244 & 135 & $<5$ & 1.3 & $60-80$ & $100-110$ \\
\hline WS:KLA (Makindye-Wabigalo,P) & 23.8 & 5.8 & 299 & 165 & $<5$ & 1.24 & $19-76$ & $4-6$ \\
\hline SL1: Lira (Adyel - Kirombe,P) & 25.5 & 6.6 & 185 & ND & ND & 0.04 & $3-5$ & ND \\
\hline SL2: Lira (Adyel - A-Nnino, (NP) & 25.2 & 6.0 & 104 & ND & ND & 0.03 & $3-4$ & ND \\
\hline
\end{tabular}


J. OKOT-OKUMU and J. OTIM / Int. J. Biol. Chem. Sci. 9(1): 552-562, 2015

\begin{tabular}{|c|c|c|c|c|c|c|c|c|}
\hline Water sources & $\begin{array}{c}\text { Temp } \\
{ }^{\circ} \mathrm{C} \\
\end{array}$ & pH & $\begin{array}{c}\mathrm{EC} \\
\mu \mathrm{S} / \mathrm{cm} \\
\end{array}$ & $\begin{array}{r}\text { TDS } \\
\mathrm{mg} / \mathrm{L} \\
\end{array}$ & $\begin{array}{c}\text { Turbidity } \\
\text { NTU }\end{array}$ & $\mathrm{NO}_{3}^{-} \mathrm{mg} / \mathrm{l}$ & $\begin{array}{c}\text { Total Coliform } \\
\text { cfu/100ml }\end{array}$ & $\begin{array}{c}\text { Faecal Coliform } \\
\text { cfu/100 ml }\end{array}$ \\
\hline SL3: Lira (Adyel - Ahali,NP) & 25.2 & 6.0 & 237 & ND & ND & 0.02 & $1-7$ & ND \\
\hline SL4: Lira (Ojwina - Kakoge A,NP) & 23 & 6.9 & 173 & ND & ND & 0.04 & $3-7$ & ND \\
\hline SL5: Lira (Ojwina - Kakoge B,P) & 25.5 & 6.8 & 127 & ND & ND & 0.01 & $3-7$ & ND \\
\hline SL6: Lira (Ojwina - Aduku Road, P) & 24.9 & 6.9 & 120 & $\begin{array}{l}\text { ND } \\
\text { Well }\end{array}$ & ND & 0.02 & $1-3$ & ND \\
\hline W-W(NP): KLA(Makindye-W) & 23.6 & 5.8 & 760 & 420.9 & $<5$ & 4.6 & $44-86$ & $0-21$ \\
\hline W: Iganga-Irongo,Kalyowa & ND & 6.8 & 209 & 127 & $<5$ & ND & ND & 4 \\
\hline W: Iganga-Ibulanku,Lusawa & ND & 6.6 & 150 & 97.5 & $<5$ & ND & ND & 10 \\
\hline W: Iganga-Irongo,Naimuli & ND & 6.6 & 131 & 80 & $<5$ & ND & ND & 3 \\
\hline \multicolumn{9}{|l|}{ Harvested rainwater } \\
\hline Rain water1 & ND & 6.4 & 36.4 & ND & $5-98$ & ND & $3-19$ & $2-3$ \\
\hline Rainwater 2 & ND & 6.1 & 34.1 & ND & $5-96$ & ND & $1-12$ & $1-2$ \\
\hline \multicolumn{9}{|c|}{ Boreholes } \\
\hline BL1: Lira (Lango College) & 24.7 & 6.9 & 195 & $\mathrm{DN}$ & ND & 0.02 & $1-2$ & ND \\
\hline BL2: Lira (Kirombe) & 25.7 & 6.4 & 128 & ND & ND & 0.03 & 1 & ND \\
\hline B3L: Lira (Adyel School) & 25.9 & 6.5 & 102 & ND & ND & 0.01 & 0 & ND \\
\hline B4: Lira (Obutuwelo) & 25.6 & 6.9 & 125 & ND & ND & 0.01 & 2 & ND \\
\hline BL5: Lira (Ober) & 24.9 & 6.3 & 195 & ND & ND & 0.02 & $0-1$ & ND \\
\hline BG: Gulu-Omoro,Cuda & ND & 7.0 & 222 & 114 & 14 & 0.02 & $0-1$ & ND \\
\hline BA: Amuru, Alero, Lulyano & ND & 7.2 & 330 & 178 & 56 & 0.4 & $1-2$ & ND \\
\hline WHO Guidelines & - & - & & & & 50 & 0 & 0 \\
\hline UNBS Standards & - & 7.0 & 2000 & 7.5 & - & 50 & 0 & 0 \\
\hline
\end{tabular}

$\mathrm{S}=$ springs; $\mathrm{P}=$ protected spring; $\mathrm{NP}=$ unprotected spring; $\mathrm{W}=\mathrm{Well}, \mathrm{ND}=$ Not Done, UNBS= Uganda National Bureau of Standards, KLA= Kampala. 
Table 2: Risk assessment scores for communities water sources ${ }^{+}$.

\begin{tabular}{|c|c|c|c|}
\hline Water sources & Risk factors recorded & Risk score & Risk of use profile \\
\hline \multicolumn{4}{|l|}{ Standpipe taps } \\
\hline T1, T2; T3; TL1; TL2; TL3; NT1; NT2; NT3 & $\begin{array}{c}(2,3,5) ;(1,2,5) ;(1,2,3,4,5,8) ;(2) ;(2) ;(2,4) ; \\
(\text { None }) ;(4,3,5) ; \text { (None) }\end{array}$ & $3 ; 3 ; 6 ; 1 ; 1 ; 2 ; 0 ; 2 ; 0$ & I; I; H; L; L; L; L;I; L \\
\hline \multicolumn{4}{|l|}{ Springs } \\
\hline $\begin{array}{l}\text { NS1(P); NS2(NP); NS3(NP); NS4(NP); NS5(P); } \\
\text { NS6(P); WS(P); SL1(P); SL2(NP); SL3(NP); } \\
\text { SL4(NP); SL5(P); SL6(P) }\end{array}$ & $\begin{array}{c}(2,7,8,910) ;(1,7,8,9) ;(1,7,8,9) ;(1,7,8,9) ;(1,2) \\
(1,2,10) ;(7,8,9,10) ;(3,4,5,7,8,10) ;(1,3,4,5,6,8,10) \\
(1,3,4,5,6,7,8,10) ;(1,2,3,4,5,6,7) ;(4) ;(2,3,4,5,6,7,10)\end{array}$ & $\begin{array}{c}5 ; 4 ; 4 ; 4 ; 2 ; 3 ; 4 ; 6 ; 7 ; 8 \\
7 ; 1 ; 8\end{array}$ & $\begin{array}{c}\text { I, I; I; I; L; I; I; H; H; H; } \\
\text { H; L; H }\end{array}$ \\
\hline \multicolumn{4}{|l|}{ Rainwater } \\
\hline R1; R2; R3 & $(1,2,3) ;(1,2) ;(1,2)$ & $3 ; 2 ; 2$ & $\mathrm{H} ; \mathrm{L} ; \mathrm{L}$ \\
\hline \multicolumn{4}{|l|}{ Boreholes } \\
\hline BL1; BL2; BL3; BL4; BL5 & $(2,5) ;(3,4,5,6,8) ;(5,6) ;(2,3,4,5,6,8) ;(3,4,5,6,8)$ & $2 ; 5 ; 2 ; 6 ; 5$ & $\mathrm{~L} ; \mathrm{I} ; \mathrm{L} ; \mathrm{H} ; \mathrm{I}$ \\
\hline \multicolumn{4}{|l|}{ Wells } \\
\hline $\mathrm{W}: \mathrm{M}-\mathrm{W}(\mathrm{NP}) ; \mathrm{W}: \mathrm{M}-\mathrm{MF}(\mathrm{P})$ & $(1,2,3,4,5,6,8,9,10) ;(1,3,4,5,6,8,9,10)$ & $9 ; 8$ & $\mathrm{VH} ; \mathrm{H}$ \\
\hline
\end{tabular}

Table 3: Classification of communities water sources.

\begin{tabular}{|c|c|c|c|c|c|c|c|}
\hline Total Coliform $/ 100 \mathrm{ml}$ & Taps & Boreholes & Protected Springs & Unprotected springs & Wells & Streams & Harvested rainwater \\
\hline$<10$ good & $57 \%$ & $100 \%$ & $43 \%$ & $43 \%$ & $0 \%$ & 0 & $33 \%$ \\
\hline 10-100 questionable & $29 \%$ & $0 \%$ & $43 \%$ & $14 \%$ & $60 \%$ & $17 \%$ & $67 \%$ \\
\hline$>100$ Poor & $14 \%$ & $0 \%$ & $14 \%$ & $43 \%$ & $40 \%$ & $83 \%$ & $0 \%$ \\
\hline
\end{tabular}




\section{DISCUSSION}

The communities except in the Rural Growth Centres (RGC) and some per-urban areas, depend entirely on groundwater and surface water sources. The urban poor have limited access to piped water and mostly rely on affordable alternative sources that are predominantly of groundwater origin. It is therefore important to assess the suitability of these water sources for community consumption since water quality has strong influence on public health that determines welfare and dignity.

An assessment of the physicochemical quality of the water sources (Table 1) was done to provide information on the suitability of the water sources for human consumption. Statistical analysis results agreed with the water sources risk classifications which is an indication that this method is acceptable to discriminate water sources. For this reason, the WHO classification is adequate for rapid assessment requirements of community water sources. However, more elaborate and robust methods that are more time consuming are in use (WHO/UNICEF, 2013) and give more details risk analysis results.

Although most of the water quality parameters are within the acceptable drinking water quality guidelines for rural water (MWE, 2006), $42 \%$ of the water sources did not meet the bacteriological drinking water standards (WHO, 2011; UNBS, 2008). This is contrary to the MWE (2011) report that stated that only 5\% are not in compliance with bacteriological guidelines. The method used by MWE is not indicated and this could be the source of disparity with our results. Bacterial contamination compromise the safe use of most of the water sources sampled because of the magnitude of health risk associated with it (Tables 2, 3).

Boreholes, taps and rainwater were the safest sources of water compared to water springs. This may be attributed to the ease of exposure to contamination of the latter water sources whose catchments are in most cases poorly managed (Nsubuga et al., 2004; Haruna et al, 2005; Parker et al, 2010). Coliform scores greater than 50 TTC in rural water supplies is an indicator of enhanced risk to the water consumers (MWE, 2006). Recent country report (MWE, 2011) also indicated protected springs in Kampala to be contaminated with faecal coliform.
Emerging public health risk is evident in many areas of Uganda especially during the rainy seasons. Rainfall events have been strongly associated with microbial contamination of water sources (Howard et al., 2003; Nsubuga et al., 2004; Kulabako et a1., 2007). Even though MWE (2011) reported accessibility to improved water sources in Uganda at $65 \%$ rural and $66 \%$ urban and estimated functionality for all water provision technologies collectively at $83 \%$ rural and $90 \%$ urban, the principal technology options for water provision are not available to all the populations. A portion of the community without access to these technologies use water from other sources such as hand scooped shallow wells, unprotected springs and surface water (streams, rivers, natural springs and lake water) to meet their daily water needs. The alternative water sources are often unsafe for drinking as illustrated by Tables 1, 2 and 3 and Figure 1.

ROC correlated very well to faecal contamination and agrees with Mushi (2012) that this is a good predictor of coliform bacteria potential of contamination of in water. This implies that sanitary inspection (used to calculate ROC) can be used as a rapid assessment method for community water sources for bacteriological contamination. It can therefore be used as stated earlier for screening to avoid unnecessary laboratory costs and save time. However confirmatory bacteriological test is advised before action decisions are made on the water sources.

Studies of ground water pollution have demonstrated that pollution risk factors model faecal contamination of wells acceptably (Howard et al., 2003; Kulabako et al., 2007; Mushi et al., 2012). Modeling is very important in discriminating the pollution/sanitary factors influence on water sources and therefore is useful in focusing management attention to factors important in a particular area. In urban slums, contamination is known to arise from latrines, solid wastes, indiscriminately disposed human faeces, animal source wastes and surface water pools (Howard et al., 2003; Kulabako et al., 2007), while in the rural areas contamination is mainly from human faeces (because of low latrine coverage), grazing and watering livestock and wild animals and birds. Rainfall is known to be a major vehicle for pollution and the predominant pollution path 
(surface input or sub-surface) depends on the area sanitary conditions, geology, hydrology and topography (Howard et al., 2003; Kulabako et al., 2007; Mushi et al., 2012).

Poor urban communities in informal settlements are found in marginal land usually low lying areas (that are usually peri-urban and high population density) with shallow groundwater that is susceptible to pollution from catchment activities. In such areas, there are poor sanitation facility coverage (OkotOkumu and Ooesterveer 2010; Okot-Okumu and Nyenje 2011; Howard et al., 2003; Kulabako et al., 2007) and poor waste disposal practices that pose high risk to water sources. Rural communities on the other hand in most cases stay in widely distributed homestead (low population density), but have very low latrine coverage and the community defecate anywhere close to where their daily activities (e.g. Digging, grazing, fetching firewood, grazing) take place, and in many cases such activities are close to communities water sources. This study and others have demonstrated that catchment anthropogenic activities and management efforts combine to influence the quality of community water sources (Howard et al., 2003; Cronin 2006; Kulabako et al., 2007; Mushi et al., 2012).

Various studies (Gleitsmann et al., 2007; Otim, 2008) have reported water use by activity by communities to be: drinking, cooking, bathing, washing dishes, washing clothes, watering livestock, irrigating flowers and trees at homestead in varying proportions. It is during the water collection and use that the communities get contaminated if the water is polluted. Community preference of available water sources depend on several factors (e.g. cleanliness, colour, distance to source, taste, smell, cost, reliability) as reported by (Howard et al., 2003; Gleitsmann et al., 2007; Otim, 2008; Lusalla, 2011; Onyango-Ouma and Gerba, 2011). OnyangoOuma and Gerba (2011) reported that some communities in western Kenya consider water to be safe provided it looks clean/clear and has no smell. This is a false belief that most African communities have that increases risk due to consumption of unsafe water. Community water sources close to footpaths and roads are also commonly used by travellers as drinking water sources. The travellers usually have no information on the safety of such water sources, but depend on their own observation of the water sources by appearance and smell. Poor communities often do not have any formal information on safe use of the water resources they depend on. The use of communities preference factors together with ROC and the WHO action priority setting matrix should be considered when planning community water source management programme. Also important is knowledge on the root causes of contamination to inform stakeholders for planning and management of the water sources.

A common tool for the identification and analysis of environmental impact on natural resources is the Causal Chain Analysis (Belausteguigoitia, 2004). Causal Chain Analysis (CCA) methods have been applied to analysis of impacts of water catchment human activities on world major water bodies (Odada et al., 2004; Wang et al., 2009). CCA concepts and principles can therefore be effectively applied to accurately identify the root causes of pollution of communities water sources, that enables tackling the problems (causes) at source (preventive activities) instead of addressing symptoms (reactive activities).

Preparing and implementing Water Safety Plans including community based on water safety monitoring can safeguard water sources ensuring improvement in water quality. Management strategies should however not only be based on water quality and physical factors but also on the institutional socio-demographic factors. An overall integrated approach would be most suitable to manage the poor communities water sources problems.

\section{Conclusion}

It has been demonstrated that boreholes and rainwater are the safest sources of water for the studied communities in Uganda. Borehole water comes from deep underground and is protected from the possible land surface pollution by the physical barrier of soil layers. Additional protection comes from the engineering considerations during construction and catchment management requirements. Rain water is a clean source of water since the atmosphere in the country is still relatively unpolluted. Water from shallow wells and springs are unsafe for human consumption and pose risks to communities. The springs and shallow wells water quality is compromised by the unsanitary conditions in their catchments. ROC was demonstrated to be a good predictor of coliform bacteria contamination of communities water sources. 
Therefore sanitary inspection (used to calculate ROC) can be used as a rapid assessment method for community water sources for bacteriological contamination. It can therefore be used for rapid screening to avoid unnecessary laboratory costs and save time. The method is easy to use and does not require any specialised training. ROC assessment methods can easily be adopted by Local Authorities for rapid screening of water sources and together with the WHO management action priority setting matrix and community water source preference can be used to plan for effective monitoring and management investments for community water sources.

\section{ACKNOWLEDGEMENTS}

The authors are very grateful to the anonymous reviewers who helped to improve this paper

\section{REFERENCES}

Aboyeji OO. 2013. Freshwater Pollution in some Nigerian local communities, Causes, Consequences and Probable Solutions. Academic Journal of Interdisciplinary Studies, 2(13): 111 117.

Awomeso JA, Gbadebo AM, Taiwo AM, Obayomi O. 2010. Hydrochemical Characteristics of springs in OkeIgbo, Ondo State, Nigeria. J. Appl. Sci. Environ. Manage, 14(3): 41 - 45.

Belausteguigoitia JC. 2004. Causal Chain Analysis and Root Causes: The GIWA approach. Ambio., 33(1-2).

Cronin AA, Breslin N, Gibson J, Pedley S. 2006. Monitoring source and domestic water quality in parallel with sanitary risk identification in northern Mozambique to prioritise protection interventions. Journal of Water and Health, 4(3): 333- 345.

Galadima A, Garba ZN, Leke L, Almustapha MN, Adam IK. 2011. Domestic Water Pollution among Local Communities in Nigeria----Causes and Consequences. European Journal of Scientific Research, 52(4): 592-603.

Haruna R, Ejobi F, Kabagambe EK. 2005.The quality of water from protected springs in Katwe and Kisenyi parishes, Kampala city, Uganda. Afri. Health. Sci., 5(1): 14-20.

Howard G, Teuton J, Luyima P, Odongo R. 2002. Water usage patterns in low- income communities in Uganda: implications for water supply surveillance. Int. J. Environ. Health. Res., 12(1): 63-73.

Howard G, Pedley S, Barret M, Nalubega M, Johal K. 2003. Risk factors contributing to microbiological contamination of shallow groundwater in Kampala, Uganda. Water Research, 37(14): 34213429.

Horak HM, Chynoweth JS, Myers WP, Davies J, Fendorf S, Boehm AM. 2010. Microbial and metal water quality in rain catchments compared with traditional drinking water sources in

East Sepik Province, Papua New Guinea. J. Wat. Health, 8(1) 126-138.

Ministry of Water and Environment. 2006. Water and Sanitation Sector performance Report. Government of Uganda (unpublished).

Ministry of Water and Environment. 2011. Water and Sanitation Sector performance Report. Government of Uganda (unpublished).

Mushi D, Byamukama D, Krischner AKT. 2012. Sanitary inspection of wells using risk-of-contamination scoring indicates a high predictive ability for bacterial faecal pollution in the peri-urban tropical lowlands of Dar es Salaam, Tanzania. J. Wat. Health., 10(2): 236243.

Nsubuga FB, Kansiime F, Okot-Okumu J. 2004. Pollution of protected springs in relation to high and low density settlements in Kampala-Uganda. Physics and Chemistry of the Earth., 29(15): 1153-1159.

Odada EO, Olago DO, Kulindwa K, Ntiba M, Wandiga S. 2014. Mitigation of Environmental Problems in Lake Victoria, East Africa: Causal Chain and Policy Options Analyses. Ambio., 33(12): 13-23.

Okot-Okumu J, Oosterveer P. 2010. Providing Sanitation for Urban Poor in Uganda. In Social Perspectives on the Sanitation Challenge, van Vliet B, Spaargaren G, Oosterveer P (eds). Springer: Dordrecht.

Okot-Okumu J, Nyenje R. 2011. Municipal solid waste management under decentralisation in Uganda. Habitat International., 35: 537-543.

Otim J. 2008. Assessment of Domestic water Quality in The Peri-urban Settlements of 
Lira Municipality. MSc Thesis. Makerere University.

Tumwine JK, Thompson J, Katua-Katua M, Mujwajuzi M, Johnstone N, Wood E, Porras I. 2002. Diarrhoea and effects of different water sources, sanitation and hygiene behaviour in East Africa. Tropical Medicine and International Health., 7(9): 750-756.

Wang L, Cai Y, Fang L. 2009. Pollution in Taihu Lake China: causal chain and policy options analyses. Front. Earth. Sci. China., 3(4): 437-444.

WHO. 2011. Guidelines for Drinking Water Quality $\left(4^{\text {th }}\right.$ edn). World Health Organisation: Geneva, Switzerland.

WHO/UNICEF. 2000. Global Water Supply and Sanitation Assessment Report. United Nations, New York.

WHO/UNICEF. 2013. WHO/UNICEF Joint monitoring programme (JMP) for water supply and sanitation. http://. www.wssinfo.org/data-estimates/ introduction/.

WHO/UNICEF. 2014. Progress on Drinking Water and Sanitation - 2014 update. WHO/UNICEF.

Wolf J, Prüss-Ustün A, Cumming $\mathrm{O}$, Bartram $\mathrm{J}$, Bonjour S, Cairncross S, Clasen T, Colford Jr JM, Curtis V, De France J, Fewtre L, Freeman MC, Gordon B, Hunter PR Jeandron A, Johnston RB, Mäusezahl D, Mathers C, Neira M, Higgins JPT. 2014. Assessing the impact of drinking water and sanitation on diarrhoeal disease in low- and middle-income settings: systematic review and meta-regression. Tropical Medicine and International Health., 19(8): 928-942. 